\title{
Microbial Contamination
}

National Cancer Institute

\section{Source}

National Cancer Institute. Microbial Contamination. NCI Thesaurus. Code C92081.

The undesirable presence of microorganisms or microbes such as bacteria and fung $\mathrm{i}$ (yeasts and molds). 